\title{
Rancang Bangun Sistem Informasi Pemberitaan di RRI Madiun Berbasis Desktop
}

\author{
Imam Abdul Malik \\ Teknik Informatika, Universitas PGRI Madiun \\ Email: imamgazpada@gmail.com
}

\begin{abstract}
ABSTRAK
Perkembangan teknologi informasi yang sangat pesat di era globalisasi saat ini telah memberikan banyak manfaat dalam kemajuan diberbagai bidang. Saat ini laporan-laporan administrasi pemberitaan RRI Madiun masih dikerjakan oleh tujuh pegawai. Selain itu, pengecekan laporan harus dilakukan satu per satu dikarenakan laporan tidak terhubung satu sama lain. Hal tersebut disebabkan karena pengerjakan laporan masih menggunakan aplikasi Microsoft Word. Laporan yang tidak saling terhubung menyebabkan terjadi ketidaksesuaian antar laporan. Tujuan penelitian ini adalah merancang dan membangun sistem informasi pemberitaan di RRI Madiun yang dapat menghasilkan laporan administrasi pemberitaan dengan mudah, cepat dan sinkron.Selain itu dapat mengoptimalkan kinerja pegawai. Model pengembangan sistem yang digunakan dalam penelitian adalah Model Waterfall. Adapun langkah pengembangan metode ini adalah sebagai berikut: analisis, perancangan, pengkodean, pengujian, penerapan dan perbaikan. Hasil dari penelitian menunjukan sistem informasi pemberitaan menghasilkan laporan pengiriman berita, laporan produksi komentar, laporan dialog, laporanpeta liputan, laporan siaranl angsung, dan laporan ROS (Report On The Spot). Kinerja staff admin di seksi pemberitaan RRI Madiun dapat dioptimalkan dengan sistem informasi pemberitaan, sehingga tidak memerlukan banyak tenaga untuk mengerjakan administrasi.
\end{abstract}

Kata Kunci : Sistem Informasi, Pemberitaan, Dekstop, RRI Madiun

\section{PENDAHULUAN}

Perkembangan teknologi informasi yang sangat pesat di era globalisasi saat ini telah memberikan banyak manfaat dalam kemajuan diberbagai bidang. Teknologi informasi juga berperan penting dalam dunia penyiaran. Pemanfaatan teknologi informasi di bidang penyiaran khususnya pada instansi radio yang sangat diperlukan untuk menunjang pada kegiatan penyiarannya.

RRI Madiun beralamatkan di Jalan Mayjend Panjaitan 10 Kota Madiun dan lebih dikenal dengan nama RRI Madiun. Dalam struktur organisasi RRI Madiun terdiri dari lima seksi meliputi Seksi Tata Usaha (TU), Seksi Siaran, Seksi Pemberitaan, Seksi Layanan dan Pengembangan Usaha (LPU), serta Teknik dan Media Baru (TMB). Di dalam seksi Pemberitaan terdiri daritiga sub seksi meliputi Sub seksi Berita, Ulasan dan Dokumentasi (Brauldok), Sub seksi Liputan dan Olahraga, serta Sub seksi
Pengembangan Berita. Banyak laporan adminitrasi yang harus diselesaikan setiap bulan termasuk di seksi Pemberitaan. Laporan-laporan administrasi di seksi pemberitaan meliputi laporan pengiriman berita melalui email, laporan pengiriman ke web, laporan produksi komentar, laporan dialog, laporan klasifikasi produksi berita, laporan peta liputan, laporan siaran langsung, dan laporan ROS (Report On The Spot). Hal itu menjadi permasalahan tersendiri di RRI Madiun khususnya Seksi Pemberitaan. Selama ini, laporan-laporan administrasi tersebut dikerjakan oleh tujuh pegawai. Selain itu, pengecekan laporan harus dilakukan satu per satu dikarenakan laporan tidak terhubung satu sama lain. Hal tersebut disebabkan karena pengerjakan laporan masih menggunakan aplikasi Microsoft Word. Laporan yang tidak saling terhubung menyebabkan terjadi ketidaksesuaian antar laporan. 


\section{KAJIAN TEORI}

Sistem adalah suatu komponenkomponen yang saling terhubung dan berinteraksibersama-sama menuju sasaran atau tujuan tertentu (Jamal dan Yulianto, 2013). Database adalah kumpulan dari data-data pada suatu basis data yang saling berhubungan satudengan yang lainnya yang tersimpan dalam perangkat keras komputer yang dapat dioleh oleh pengguna (Khoirul dan Riasti, 2017). MySQL adalahsebuah aplikasi basis data bersifat gratis yang menggunakan standar bahasa kueri SQL(Structure Query Language) untuk melakukan pemrosesan data (Novita dan Sari, 2015). Java adalah suatu bahasapemrograman yang gratis, java juga merupakan platform (Prasetyo dan Arliando, 2015). Netbeans adalah sebuah IDE (Integrated Development Environment) open source yang dapat digunakan untuk bahasa pemrogaramn Java, PHP, Python, Ruby dan lain-lain. Bagan alir sistem (systems flowchart) merupakan bagan yang menggambarkan suatu proses dalam program yang menjelaskan secara rinci langkah-langkah dari proses dokumen dengan menggunakan simbol-simbol tertentu (Purnamayudhia, 2015). Data Flow Diagram adalah suatu model logika data yang digunakan untuk menggambarkan aliran data pada suatu program dengan menggunakan simbol-simbol tertentu (Wibowo, 2014). ERD adalah suatu model yang digunakan untuk menjelaskanhubungan antar data dalam basis datayangmempunyai hubungan antar relasi dengan menggunakan simbolsimbol tertentu (Fakhudin, 2016).

\section{METODE PENELITIAN}

Pada penelitian ini peneliti menggunakan model pengembangan waterfall. Model waterfall adalah suatu model yang bersifat sistematis, berurutan dalam membangun software. Adapun yang menjadi sumber data primer dalam penelitian ini adalah pegawai RRI Madiun. Adapun sumber data sekunder dalam penelitian ini adalah dokumen yang didapatkan meliputi laporan pengiriman berita, laporan produksi komentar, laporan dialog, laporan produksi, laporan peta liputan, laporan siaran langsung, dan laporan ROS. Teknik pengumpulan data yang digunakan adalah wawancara, observasi, studi pustaka. Adapun flowchart rancangan penelitian yang dilakukan peneliti dalam menyelesaikan penelitian yaitu:

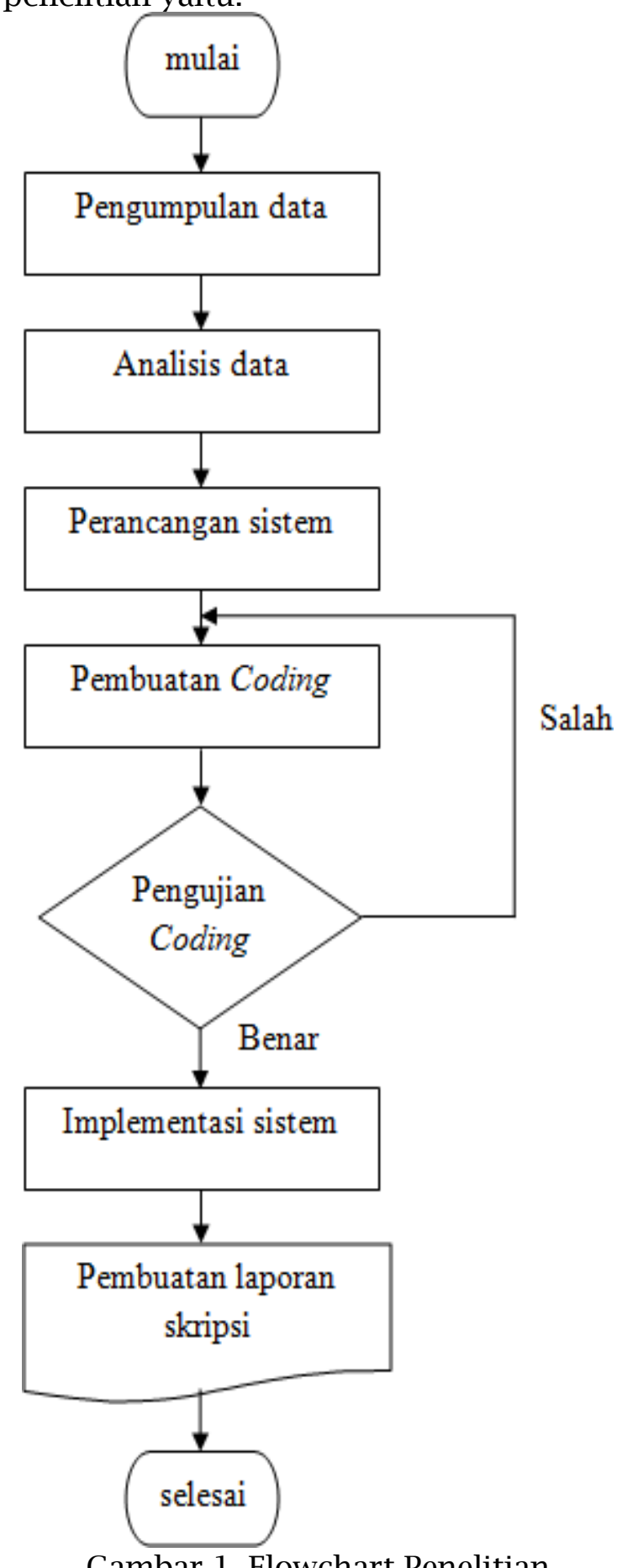

Gambar 1. Flowchart Penelitian 
HASIL DAN PEMBAHASAN

\section{A. Perancangan}

1. Flowchart Adminsitrasi

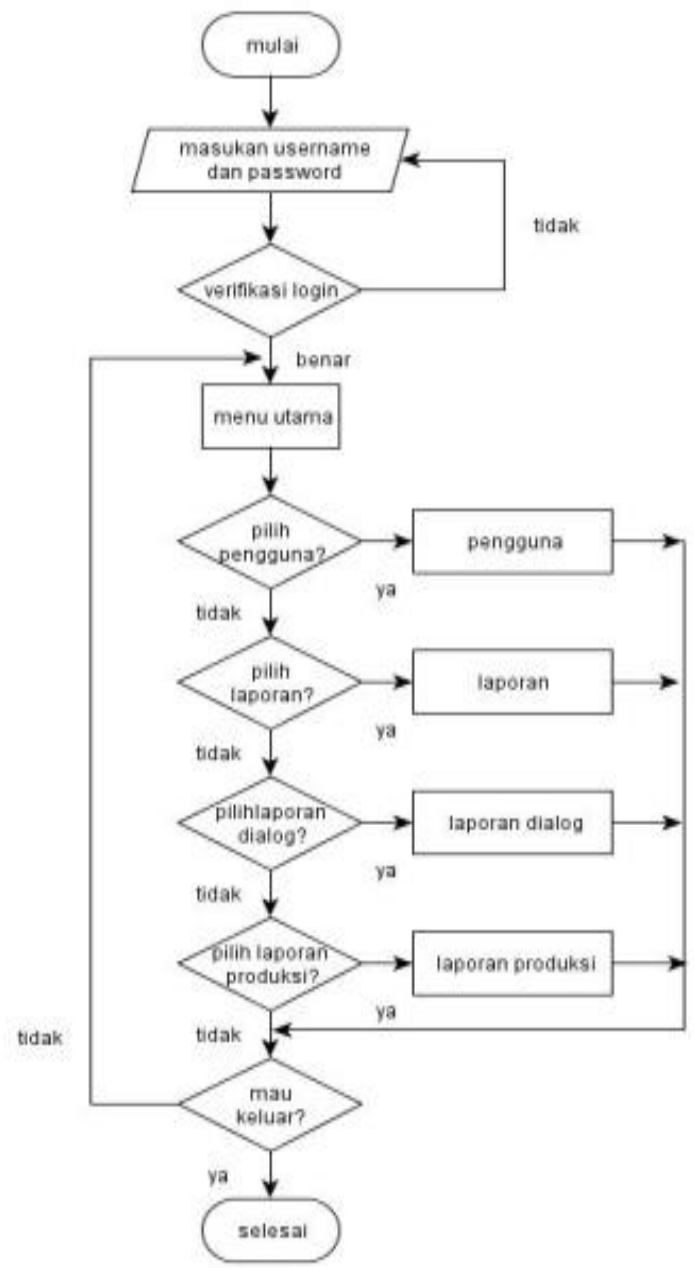

Gambar 2. Flowchart Adminsitrasi

2. DFD level 0

Berikut adalah DFD Level 0 sistem yang akan dibangun.

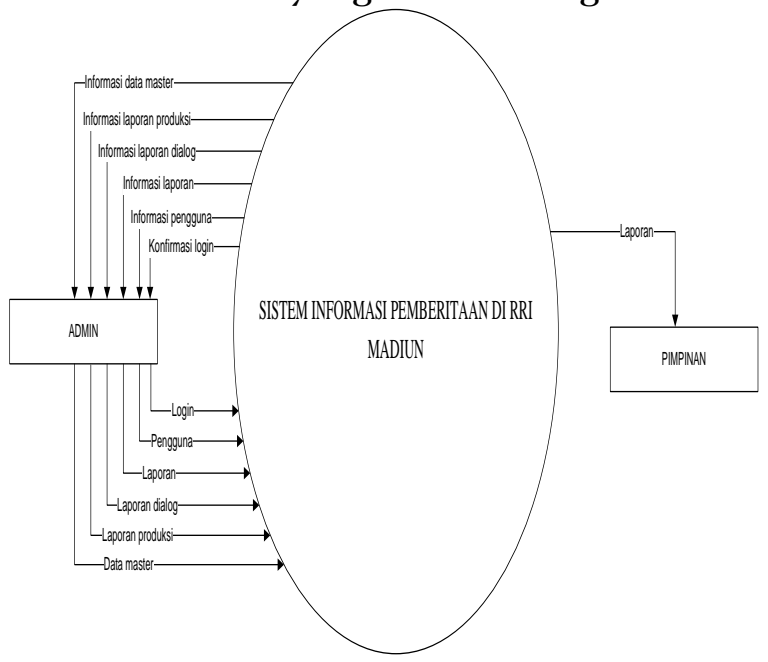

Gambar 3. DFD Level 0
3. DFD level 1

Berikut adalah DFD Level 1 sistem yang akan dibangun..
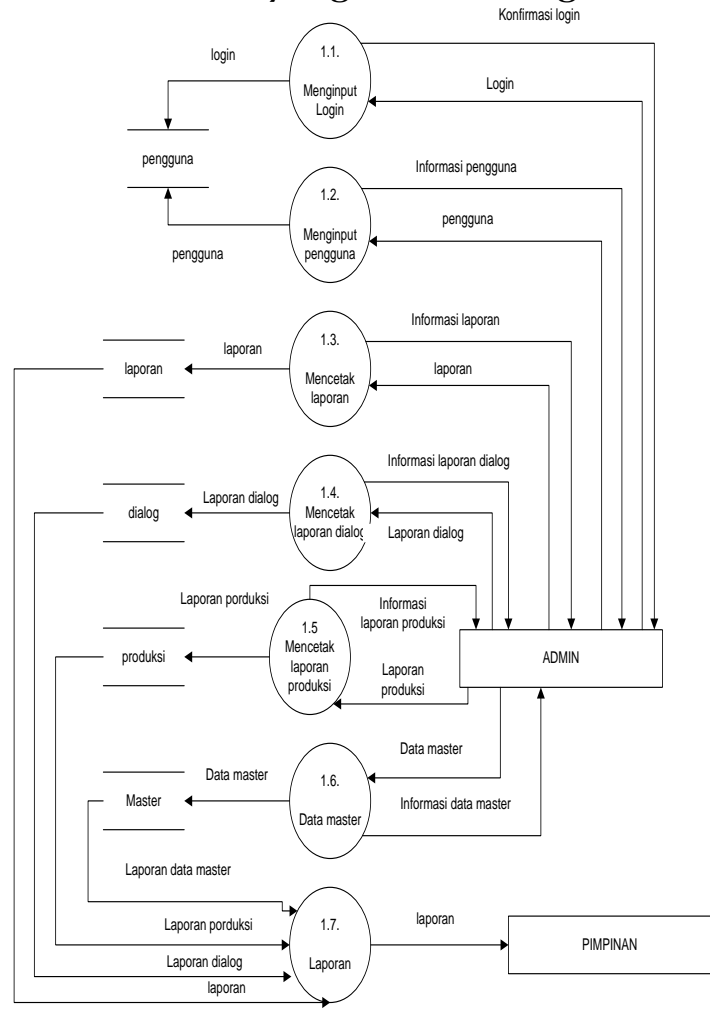

Gambar 4. DFD Level 1

4. ER-Diagram

Berikut adalah ER-Diagram sistem yang akan dibangun..

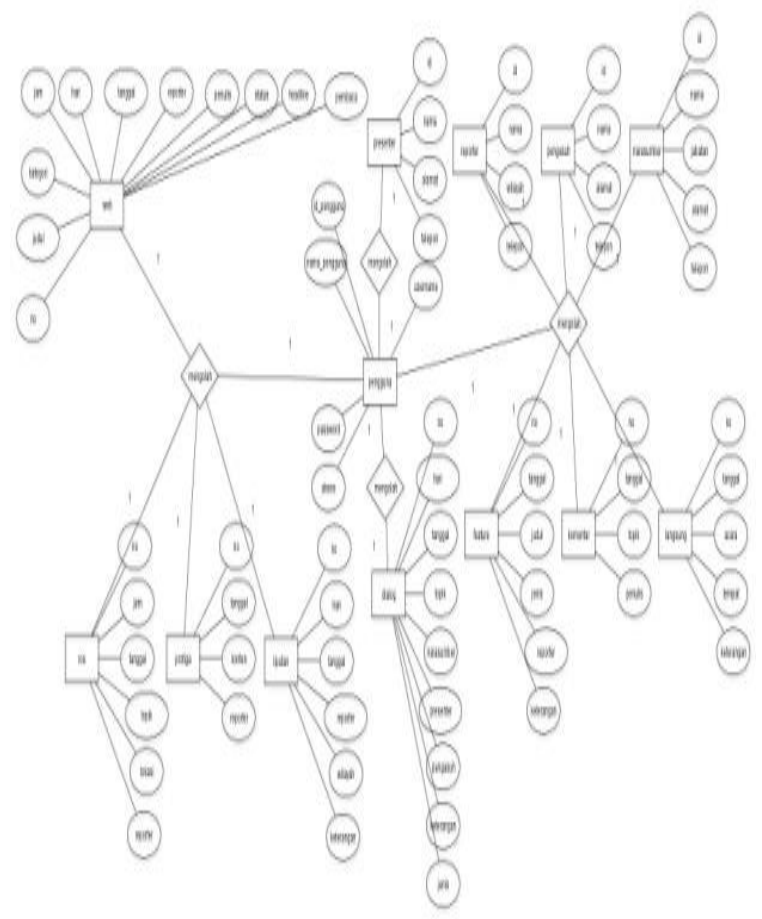

Gambar5. ER-Diagram 


\section{B. Hasil dan Pembahasan}

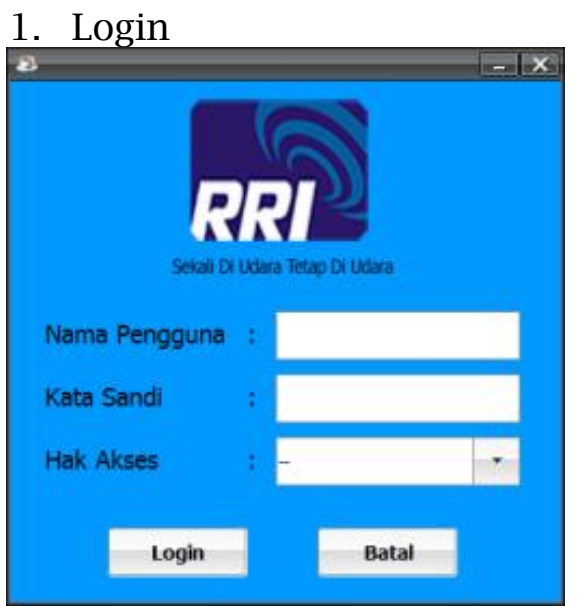

Gambar 6. Login Aplikasi

2. Menu Utama

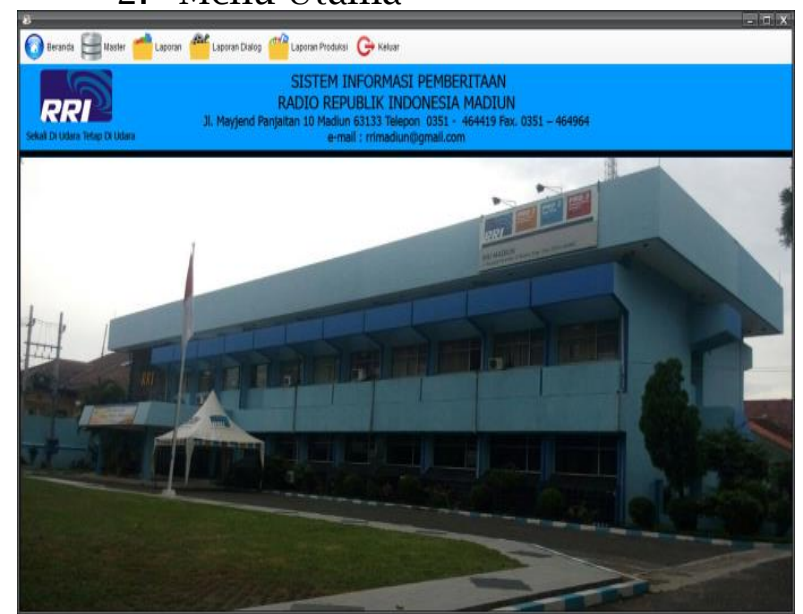

Gambar 7. Menu Utama Aplikasi

3. Data Pengguna

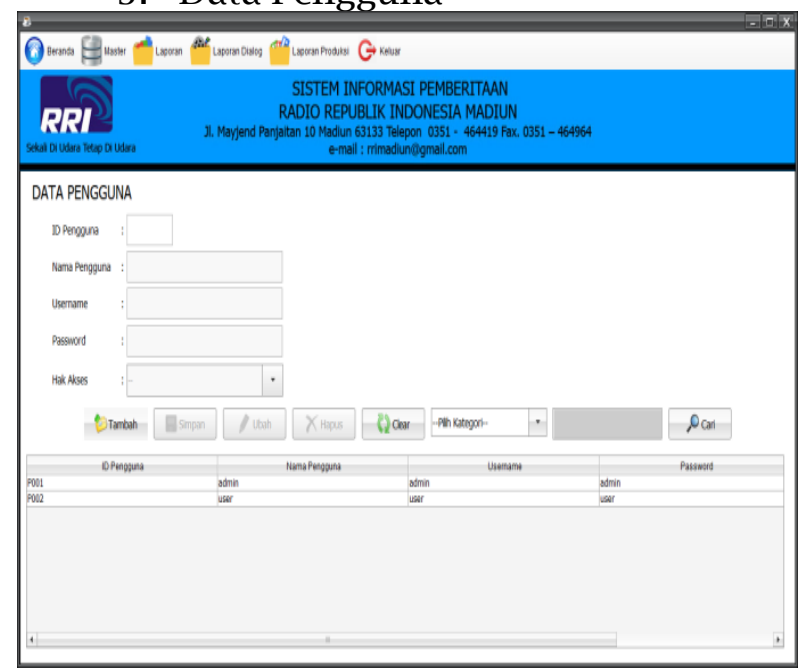

Gambar 8. Data Pengguna Aplikasi

\section{Data Reporter}

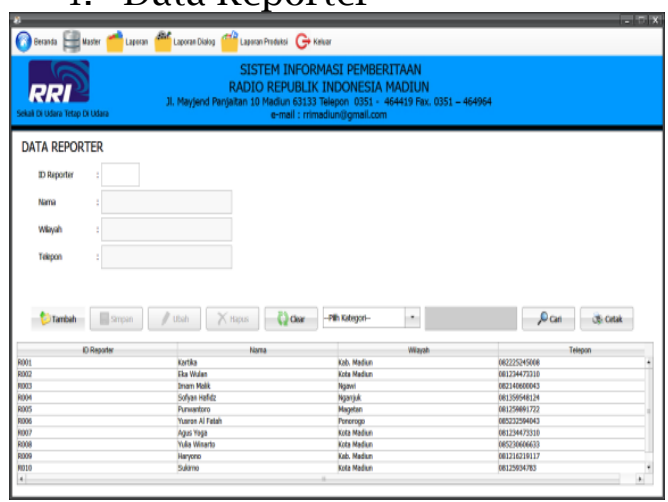

Gambar 9. Data Reporter Aplikasi

5. Data Pengasuh

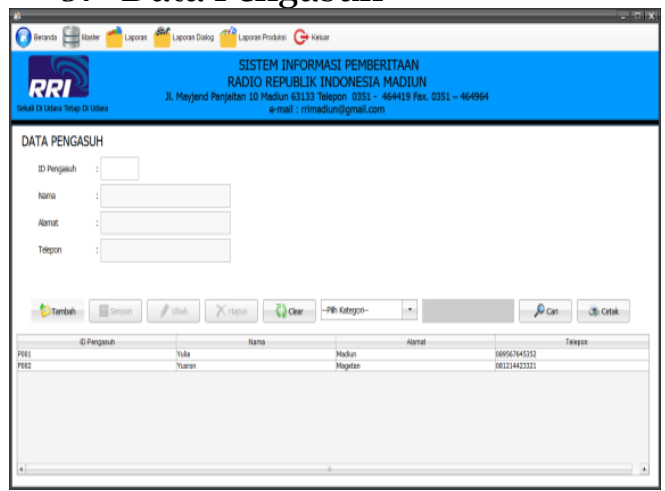

Gambar 10. Data Pengasuh Aplikasi

6. Data Presenter

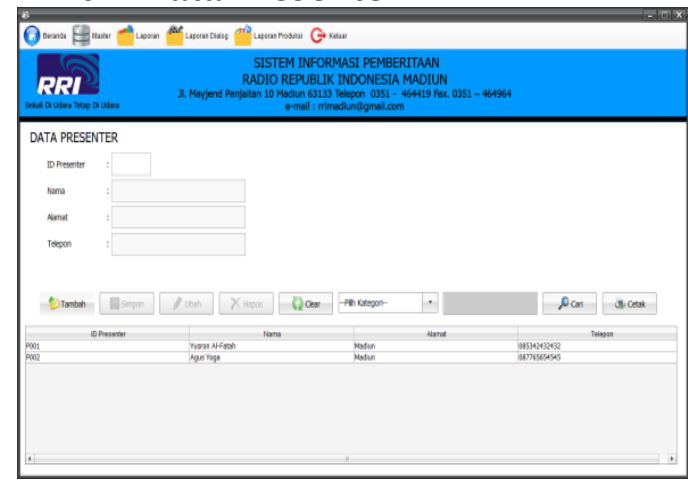

Gambar 11. Data Presenter Aplikasi

7. Data Narasumber

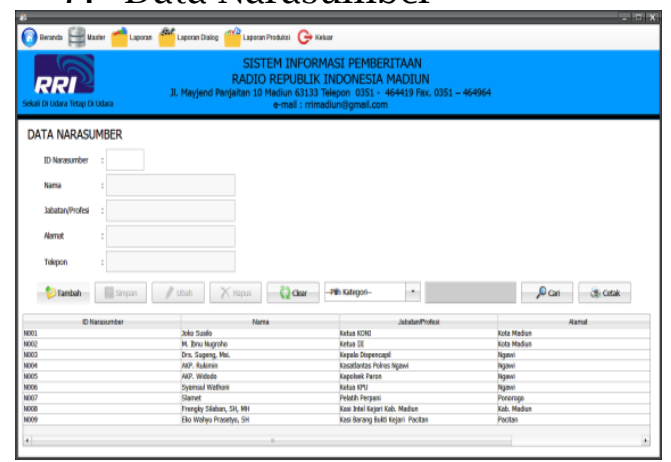

Gambar 12. Data Narasumber Aplikasi 
8. Laporan Narasumber

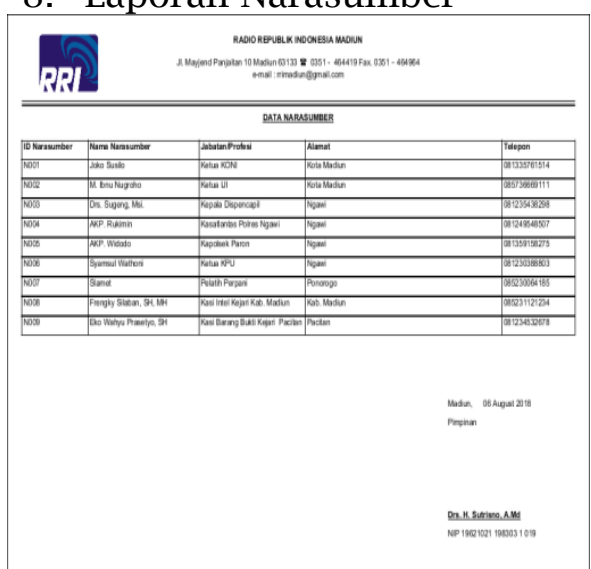

Gambar 13. Laporan Narasumber Aplikasi 9. Laporan Presenter

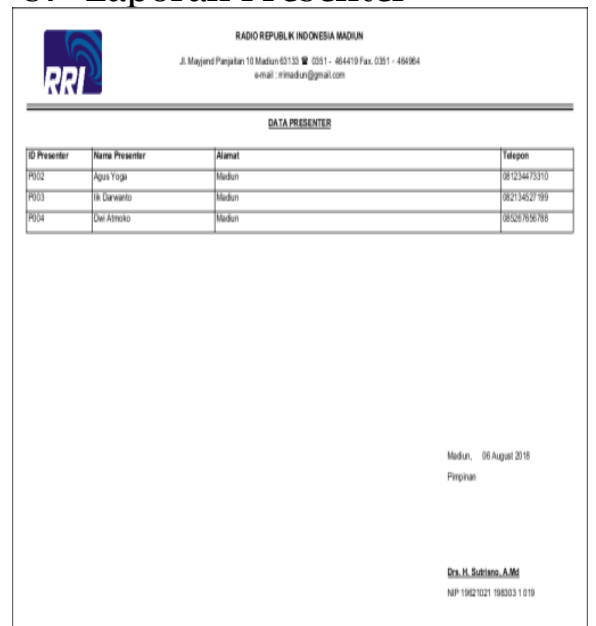

Gambar 14. Laporan Presenter Aplikasi

10. Laporan Reporter

Menu inidigunakan untuk mencetak laporan reporter.

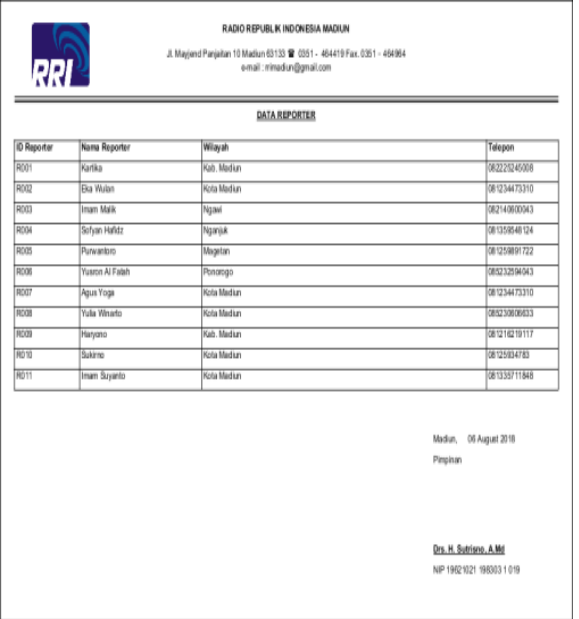

Gambar 15. Laporan Reporter Aplikasi

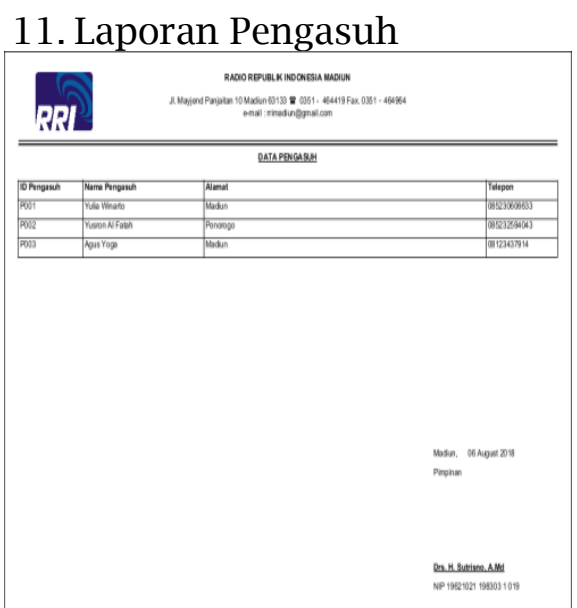

Gambar 16. Laporan Pengasuh Aplikasi

\section{Pengujian Sistem}

Berdasarkan hasil jawaban dari 5 responden atas pertanyaan kuisioner yang sudah dilakukan menunjukan bahwa 100\% responden memilih sangat setuju. Berdasarkan hal tersebut dapat dikatakan bahwa sistem informasi pemberitaan yang dibangun sangat layak digunakan di RRI Madiun.

\section{Pembahasan}

Hasil dari penelitian menunjukan bahwa sistem informasi pemberitaan dapat mempermudah dalam mengolah beberapa data pemberitaan di RRI Madiun meliputi data pengguna, narasumber, reporter, pengasuh, presenter, peta liputan, pengiriman berita ke pro3, berita web, ROS (Report On The Spot), dialog, komentar, feature, dan siaran langsung.

\section{KESIMPULAN}

Kesimpulan dalam penelitian ini adalah dapat merancang dan membangun sistem informasi pemberitaan di RRI Madiun berbasis dekstop.Sistem informasi pemberitaan menghasilkan laporan pengiriman berita, laporan produksi komentar, laporan dialog, laporan peta liputan, laporan siaran langsung, dan laporan ROS (Report On The Spot).Kinerja staff admin di seksi pemberitaan RRI Madiun dapat dioptimalkan dengan sistem informasi pemberitaan, sehingga tidak memerlukan 
banyak tenaga untuk mengerjakan administrasi.

\section{DAFTAR PUSTAKA}

A. Fatkhudin. 2016. "Sistem Informasi Penjualan Dan Pembelian Pada Toko Elektronik Lubada Jaya Kajen Dengan Menggunakan Java," Jurnal Digit, vol. 6, no. 1, p. 25.

A. Jamal and L. Yulianto. 2013. "Rancang Bangun Sistem Informasi Aplikasi Kasir Menggunakan Barcode Reader Pada Toko Dan Jasa Widodo Computer Ngadirojo Kabupaten Pacitan," Journal Speed - Sentra Penelitian Engineering dan Edukasi, vol. 5, no. 3 , p. 46.

G. I. Wibowo, A. M. Rumagit and N. J. Tuturoong. 2013. "Perancangan Aplikasi Gudang Pada PT. Pakan Ternak Sejati," E-Journal Teknik Elektro dan Komputer, p. 12.
M. H. Prasetyo, Asnawati and Y. Arliando, "Sistem Informasi Nilai Mahasiswa Berbasis Sms Gateway Pada Fakultas Pertanian Universitas Bengkulu," Jurnal Media Infotama, vol. 11, no. 1, p. 13.

M. Khoirul, T. I. Tjendrowasono and B. K. Riasti. 2017 "Aplikasi Pengelolaan Data Kearsipan Pada Sekolah Menengah Atas Negeri 1 Mlonggo Jepara Berbasis Multiuser," IJNS - Indonesian Journal on Networking and Security, p. 3

O. Purnamayudhia. 2015. "Aplikasi Sistem Informasi Penjualan Obat Di Apotek Dengan Menggunakan Metode Visual Basic 6," Jemis, vol. 3, no. 2, pp. 87-88.

R. Novita and N. Sari. 2015. "Sistem Informasi Penjualan Pupuk Berbasis E-Commerce," Jurnal Teknoif, vol. 3, no. 2, pp. 2-3. 